\author{
Andrijana S. Đordan* \\ Alfa BK Univerzitet \\ Fakultet za strane jezike \\ Sanja Maričić Mesarović** \\ Univerzitet u Novom Sadu \\ Filozofski fakultet
}

\title{
JEZIK U DOBA PANDEMIJE KOVIDA-19: TERMINOLOŠKA REŠENJA U SRPSKOM I ŠPANSKOM JEZIKU***
}

\author{
Originalni naučni rad \\ UDC $811.163 .41^{\prime} 27 ' 26$ \\ $811.134 .2^{\prime} 27^{\prime} 26$ \\ https://doi.org/10.18485/kkonline.2020.11.11.3
}

\begin{abstract}
Pojava virusa SARS-CoV-2 i pandemije koju je izazvao rezultirala je potresima u svim sferama života savremenog čoveka, te je prirodno da su dati virus i bolest u centru pažnje celokupne svetske javnosti poslednjih meseci. Informacije o njima i merama koje se preduzimaju da se suzbije njihovo širenje objavljuju se i prenose na svim živim jezicima i putem svih kanala komunikacije (štampanih i elektronskih medija, društvenih mreža, veb-sajtova zvaničnih zdravstvenih i državnih institucija, usmenim i pisanim saopštenjima, itd.). Cilj ovog rada je da kroz analizu određenog korpusa medijskih tekstova i zvaničnih saopštenja relevantnih institucija (pre svega Svetske zdravstvene organizacije i nadležnih tela u Srbiji i Španiji) osmotri terminološka rešenja imenovanja virusa i bolesti u srpskom i španskom jeziku i skrene pažnju na određene terminološke, pravopisne i gramatičke nedoumice koje tom prilikom nastaju. Polazna pretpostavka je da su, kako u srpskom, tako i u španskom jeziku, postojale (ili postoje?) nedoumice u imenovanju virusa i bolesti i načinu pisanja njihovih naziva. Konačno, za sve prepoznate jezičke neispravnosti ili nepreciznosti pokušaćemo da ponudimo adekvatna rešenja.
\end{abstract}

Ključne reči: SARS-CoV-2, kovid-19, terminologija, srpski jezik, španski jezik.

\section{Uvod: predmet i metodologija rada}

Odnos jezika i društvenih pojava je širok i kompleksan. Govoreći o odnosu jezika i društvenih promena Bugarski polazi od dve fundamentalne i neosporne pretpostavke - jezik i društvo su povezani i podložni promenama (Bugarski, 1976: 2). Premda autor podvlači da jezičke promene (koje su znatno sporije od društvenih) prvenstveno

\footnotetext{
* Alfa BK univerzitet, Palmira Toljatija 3, 11000 Beograd, Srbija; e-mail: andrijana.djordan@alfa.edu.rs ** Filozofski fakultet Univerziteta u Novom Sadu, Dr Zorana Đinđića 2, 21000 Novi Sad, Srbija; e-mail: sanja.maricic.mesarovic@ff.uns.ac.rs

*** Ovaj članak predstavlja rezultat rada na projektu „Jezici i kulture u vremenu i prostoru” (br. 187002), koji je finansiran od strane Ministarstva prosvete, nauke i tehnološkog razvoja Republike Srbije.
} 
prouzrokuju društvene, jasno je da taj odnos nikako nije jednosmeran i da se uticaj jezika na oblikovanje stvarnosti ne može zanemariti.

Novine u društvu na polju jezika najbrže i najjasnije se vide u leksici. Novi pojmovi iziskuju svoje jezičke realizacije, odnosno jezičko otelotvorenje u vidu termina.

Jedna od najbitnijih promena u toku 21. veka koje čovečanstvo pamti, počela je u decembru 2019. godine, kada je "novi virus", potekao iz univerzitetskog grada Vuhana (provincija Hubei, centralna Kina), krenuo munjevitom brzinom da se širi najpre u lokalnoj, a onda i celokupnoj ljudskoj populaciji. Od tada, pa do danas, uz upliv vesti o ratnim žarištima ili predizbornim kampanjama i postizbornim dešavanjima, informacije o novom respiratornom virusu, bolesti koju izaziva i njenim posledicama preplavljuju svetske medije i uopšte komunikaciju celokupnog čovečanstva. U martu 2020. godine, kada je ovaj virus zvanično registrovan u Srbiji i kada je njegovo prisustvo u potpunosti promenilo svakodnevicu, postao je ključna tema u našoj zemlji, a refleksije date situacije u srpskom jeziku privukle su pažnju autorki ovog rada, koju smo kasnije kao hispanistkinje, usmerile i na španski jezik. Iako je ova tema svetu poznata nepunu godinu, intenzitet njenog prisustva i njena važnost doprineli su da se analizira iz različitih aspekata - naravno, prvenstveno medicinskog, ali i ekonomskog, političkog, sociološkog, psihološkog, jezičkog, umetničkog i brojnih drugih. Dosadašnja istraživanja iz oblasti jezika u vezi sa ovom temom tek ozbiljnije kreću, mada je i do sada objavljen značajan broj radova (prvenstveno u Kini). Oni se najpre tiču (ne)postojanja pristupa informacijama o pandemiji na manjinskim jezicima i uopšte jezičke raznolikosti i višejezičnosti u vremenu date zdravstvene krize Piller, Zhang \& Li, 2020; Zhang, Wu, 2020; Li, Xie, Ai \& Li, 2020), problema prevođenja i terminoloških problema (Zheng: 2020), (kritičke) analize diskursa političkih govora, medijskih izveštaja, tekstova na društvenim mrežama, nastave jezika u doba pandemije i izazovima pred kojima se nalaze kako učenici, tako i nastavnici (Gao, LX., Zhang, LJ., 2020. itd.).

Predmet istraživanja ovog rada su terminološka rešenja za naziv virusa i bolesti u srpskom i španskom jeziku (u Španiji), kao i pravopisne i gramatičke nedoumice koje su primećene u ovim jezicima, a nastale su i ponavljale se (ponavljaju se) u tekstovima koji se bave ovom temom.

Iz metodološkog ugla posmatrano, rad se zasniva na istraživanju rađenom na korpusu tekstova iz dnevnih novina u Srbiji i Španiji i tekstovima sa veb-sajtova Svetske zdravstvene organizacije (World Health Organization), kao i državnih tela (u 
Srbiji i Španiji) zaduženih da se bave ovom temom i komuniciraju sa javnošću. Precizan opis korpusa dat je u trećem poglavlju rada.

Polazne pretpostavke su da su u oba jezika termini koji se koriste da označe virus i bolest nestabilni (u srpskom, verovatno izrazitije), tj. da se pojavljuje više varijanti koje se koriste paralelno, često neprecizno i sa neujednačnom ortografijom.

\section{Naziv virusa i bolesti - pogled iz ugla terminologije}

Novi virus, kao što je rečeno, prvo se pojavio u Kini i vest o njemu pronela se svetom na brojim jezicima, a prirodno i očekivano, međunarodna komunikacija i na ovu temu odvijala se (i odvija se) prvenstveno na engleskom jeziku koji je globalna lingua franca savremenog sveta. I pre nego što je dobio zvaničan naziv u stručnim krugovima u februaru 2020. godine, virus je postao jedna od gorućih tema. Ako tome dodamo činjenicu da jezička promena/pojava koja prati društvenu promenu/pojavu nastaje sporije i zahteva vreme da se stabilizuje (Bugarski, 1976: 2), ne čudi što je na mnogim jezicima postojalo više naziva za novi virus i bolest čiji je on uzročnik.

Kako naziv virusa, tako i naziv bolesti predstavljaju (medicinske) termine struke. Termini struke su jezičke realizacije pojmova struke, osobeni nosioci značenja i deo su domena stručne upotrebe jezika, odnosno diskursa jezika za posebne namene. Đordan (2016: 43) podseća da, kako termini, tako i „obične reči” imaju formalni, semantički i funkcionalni aspekt, jer pripadaju utvrđenom kodu, ali i pragmatički, jer su nosioci stručne komunikacije u kojoj predstavljaju pojmove određenih disciplina. Upravo pragmatička i komunikativna perspektiva predstavljaju razliku između reči jezika za opštu namenu i termina kao jedinica jezika za specifične namene.

Lera (Lérat, 1989) opisuje termin kao konvencionalni simbol koji predstavlja pojam definisan u okviru određene oblasti znanja. Termin mora biti rezultat konvencije, odnosno dogovora, a njegova ključna odlika mora biti sadržina, odnosno semantička težina, mora biti jasno definisan i upućivati na oblast kojoj pripada.

Kako je objašnjeno na sajtu Svetske zdravstvene organizacije (World Health Organization $)^{1}$, virusi se imenuju na osnovu svoje genetske strukture, a u svrhu lakšeg razvoja dijagnostičkih testova, vakcina i lekova. Za imenovanje virusa zadužen je Međunarodni komitet za taksonomiju virusa (International Committee on Taxonomy of Viruses). Nazive bolesti određuje Svetska zdravstvena organizacija. Dva navedena tela odlučila su 11. februara 2020. godine da naziv novog virusa na engleskom jeziku

https://www.who.int/emergencies/diseases/novel-coronavirus-2019/technical-guidance/naming-thecoronavirus-disease-(covid-2019)-and-the-virus-that-causes-it 
bude severe acute respiratory syndrome coronavirus 2 (SARS-CoV-2), u prevodu teški akutni respiratorni sindrom koronavirus 2 (SARS-CoV-2), dok je bolest nazvana coronavirus disease COVID-19 (COVID je akronim od coronavirus disease, a 19 označava 2019, godinu kada je virus registrovan).

Iako su nazivi za virus i bolest već formirani kao termini struke na engleskom jeziku, skrenuli bismo pažnju na činjenicu da je pitanje kakvi stručni termini zapravo treba da budu tema brojnih studija i rasprava poznavalaca datih struka, terminologa, stručnjaka za korpusnu lingvistiku, sociolingvistiku i uopšte jezičkih stučnjaka. U procesu izgradnje, sistematizovanja, standardizacije i prihvatanja naučnih termina Bugarski (2007: 92) izdvaja četiri grupe kriterijuma: formalne (dužina, lakoća izgovora i pisanja i sl.), semantičke (adekvatnost pojmu, preciznost, motivisanost, prozirnost, jednojezičnost/ višejezičnost, sinonimija/ homonimija itd.), pragmatičke (prihvatljivost jezičkom osećanju, odomaćenost, ekonomičnost, stabilnost, rasprostranjenost, itd.) i sociolingvističke (jezici sa stanovišta sistemskih mogućnosti i vrednosti koje kolektivi za njih vezuju). Baveći se terminima generativne gramatike on formira hijerarhizovanu matricu za sistematsko vrednovanje termina ${ }^{2}$, gde se kao kriterijumi po hijerarhiji, od najvišeg naniže navode sledeći: sistemnost, produktivnost, jednoznačnost, internacionalnost, motivisanost, raširenost, stabilnost, konotacije, kratkoća, lakoća (Bugarski, 2007: 109). Šipka (1998: 128) kao ključne osobine stručnog termina izdvaja: transparentnost, internacionalnost, ustaljenost (opšteprihvaćenost u datoj disciplini), kratkoću, sistemnost (uklopljivost u terminološki sistem), nedvosmislenost, preciznost i sinonimnost. Filipović i Filipović (1997) primećuju da su, prema mišljenju većine istraživača, ključne osobine termina internacionalnost, kratkoća i jednoznačnost. Analizom sportske terminologije u srpskom jeziku Milić (2013: 81-82) zaključuje da idealan termin treba da zadovoljava principe jednoznačnosti i nesinonimnosti sa stanovišta struke; sistemnosti, prozirnosti i produktivnosti sa stanovišta jezičkog standarda; kratkoće i učestalosti sa gledišta pragmatičnosti.

Generalno posmatrano, kao ključne osobine termina struke izdvajaju se jednoznačnost, nesinonimnost, kratkoća i internacionalnost. Pretpostavljamo da su spomenuta tela koja su na engleskom jeziku virus označila kao SARS-CoV-2, a bolest kao COVID-19, vodila računa o tim aspektima, a mi ćemo u daljem radu obratiti pažnju

\footnotetext{
2 Data hijerarhizovana matrica za vrednovanje stručnih termina može biti modifikovana po potrebi (mesto u hijerarhiji, broj kriterijuma i sami kriterijumi mogu se menjati).
} 
da li su ti ključni kriterijumi zadovoljeni u terminima na srpskom, odnosno španskom jeziku.

Pošto su termini struke, između ostalog, pragmatičke jedinice, Kabre (Cabré, 1999: 12) ističe pet pragmatičkih faktora koji terminologiju razlikuju od jezika za opšte namene: svrhu (namenu), temu, korisnika, komunikativnu situaciju u kojoj se javljaju i vrstu diskursa u kom se javljaju. Jezik za opštu namenu ima performativnu, ekspresivnu, komunikativnu svrhu, dok je kod terminologije svrha referencijalna. U prvom slučaju teme su opšte, generičke, dok se terminologija koristi u temama specijalizovanih oblasti. Jezik za opšte namene koristi se u svakodnevnim komnikativnim situacijama i karakterističan je za opšti diskurs, a terminologija u specifičnim strukturiranim komunikativnim situacijama i vezana je za stručni i naučni diskurs. Ove granice su, svakako, okvirne, a da je aktuelni virus manje invazivan i da se sporije širi, verovatno bi bile prilično primenljive na termine koji označavaju njega i bolest koju izaziva. Ipak, još pre nego što je struka stigla da imenuje ove nove pojave, one su postale deo svakodnevne stvarnosti sveta, pa su tako i ušle u jezik svakodnevne komunikacije.

U nastavku rada analiziraćemo nazive za novi virus i bolest koji su u upotrebi u srpskom i španskom jeziku - videćemo kako su ti oblici formirani i kako se, kao termini struke koji su preplavili svakodnevnu komunikaciju, u njoj ponašaju.

\section{Predstavljanje istraživanja}

Kako bismo utvrdile nazive kojima su virus i bolest označeni u srpskom i španskom jeziku izabrale reprezentativan korpus u kom ćemo ih identifikovati, a koji Čine:

- za srpski jezik: tekstovi onlajn izdanja dnevnog lista Politika od 6.3.2020. godine, tj. dana kada je ustanovljen prvi slučaj ovog virusa u Srbiji, kao i naslovi i tekstovi istog lista objavljeni šest meseci kasnije, odnosno 6.9.2020. godine.

- za španski jezik: tekstovi onlajn izdanja dnevnog lista El País od 31.1.2020. godine, tj. dana kada je ustanovljen prvi slučaj ovog virusa u Španiji, kao i naslovi i tekstovi istog lista objavljeni šest meseci kasnije, odnosno 31.6.2020. godine. 
Tekstove od dana kada se pojavio prvi slučaj zaraze u dve navedene zemlje izabrali smo sa pretpostavkom da je ta vest bila ključna datog dana, te da je fokus, kako autora, tako i čitalaca bio na njoj. Tekstove objavljene šest meseci nakon registrovanja prvog slučaja zaraze odabrale smo jer smatramo da je dati period dovoljan da se koriguju (ako je bilo potrebno) i relativno stabilizuju jezički oblici (terminološki, gramatički, pravopisni) koji se odnose na ovu temu.

Pored navedenih tekstova naše istraživanje uključilo je i tekstove sa zvaničnog veb-sajta Svetske zdravstvene organizacije (verzije na engleskom, kao jeziku globalne komunikacije i španskom jeziku; verzija na srpskom jeziku ne postoji), nacionalnih zdravstvenih državnih organizacija (specijalizovanog veb-sajta koji se u Srbiji bavi ovom temom ${ }^{3}$ i Ministarstva zdravlja, potrošnje i socijalnog staranja Kraljevine Španije ${ }^{4}$.

Analizirale smo, takođe, reakcije koje su na nazive za virus i bolest imale relevantne jezičke institucije u Srbiji (Odbor za standardizaciju srpskog jezika) i Španiji (Španska kraljevska akademija za jezik).

$\mathrm{Na}$ ovaj način obezbedile smo uvid u refleksije aktuelne zdravstvene situacije na svakodnevni jezik - jezik štampe, ali i jezik zvaničnih kanala preko kojih države obaveštavaju građane o ovoj važnoj temi. Svemu navedenom, priložile smo i reakcije i stavove tela koja se bave srpskim i španskim jezikom, te time pokušale da predstavimo celovitu sliku tretiranih jezičkih aspekata.

\subsection{Naziv virusa i bolesti u srpskom jeziku}

U Republici Srbiji, kao što je spomenuto, prvi slučaj novog virusa zvanično je registrovan 6.3.2020. godine, a dnevni list Politika u onlajn izdanju toga dana spominje ga u jedanaest sledećih naslova ${ }^{5}$ :

1. Proverava se još jedna osoba na prisustvo koronavirusa

2. Šesnaestogodišnjak smešten u karantin leskovačke bolnice zbog sumnje na koronavirus

3. Vučić: Nema mesta panici zbog koronavirusa

4. Korona virusom zaraženo više od sto hiljada ljudi u svetu

5. Zaraženi kovidom 19 u skoro svakoj zemlji Evrope

6. Alitalia otkazala letove na liniji Rim-Beograd zbog Kovid-19

\footnotetext{
${ }^{3}$ https://covid19.rs/

4 https://www.mscbs.gob.es/profesionales/saludPublica/ccayes/alertasActual/nCov/situacionActual.htm

5 U obzir smo uzeli cele tekstove, a ovde izdvajamo samo naslove; podebljanja reči u naslovima su naša.
} 
7. Zbog koronavirusa odlažu se ekskurzije u inostranstvo

8. Prvi slučaj koronavirusa u Vatikanu

9. Ministarstvo zdravlja zbog koronavirusa sprema karantin za migrante

10. Potvrđen prvi slučaj koronavirusa u Srbiji - muškarac iz Subotice boravio je u Budimpešti

11. Epidemija nije vežba, moramo zaustaviti koronavirus

Pola godine nakon što je potvrđen prvi slučaj zaraze, 6.9.2020. godine u onlajn izdanju Politike pronalazimo samo jedan naslov sa nazivom koji pratimo:

1. Na KiM 92 osobe pozitivne na kovid-19, devet preminulo

Zvaničan veb-sajt putem kog država informiše građane o novom virusu, www.covid19.rs, formiran je u saradnji Ministarstva zdravlja i Instituta za javno zdravlje Srbije "Dr Milan Jovanović Batut”. U okviru glavnog menija isti nudi segment Статистички подаци о корона вирусу, a dnevnu statistiku objavljuje na početnoj strani pod naslovom СТАТИСТИЧКИ ПОДАЦИ О ВИРУСУ COVID-19 У РЕПУБЛИЦИ СРБИЈИ. Na ovom veb-sajtu naći ćemo i sledeće rečenice (preuzete doslovno, uključujući i pismo (veb-sajt je na ćirilici)):

\section{9;}

у Републици Србији је регистровано укупно 35, 251 случајева COVIDслучајева инфекције изазване новим корона вирусом (COVID-19);

Кинеске власти су идентификовале нови коронавирус 7. јануара и вирус је привремено назван „2019-nCoV". 11. фебруара, болест изазвана овим вирусом названа је Коронавирус 2019, или „COVID-19".;

Корона вируси (CoV) представљају велику породицу вируса који изазивају болести које се крећу у опсегу од обичне прехладе до озбиљних обољења као што су MERS (Блискоисточни респираторни синдром) и SARS (Тешки акутни респираторни синдром).;

COVID-19 је обољење изазвано новим корона вирусом, што значи да пре тог није био пронађен.

Ukoliko objedinimo sve nazive za virus i bolest koje smo identifikovale u navedena dva izvora, dobićemo sledeće termine:

\begin{tabular}{|l|l|l|l|l|}
\hline \multicolumn{2}{|c|}{ Izvor } & \multicolumn{2}{c|}{ naziv virusa } & \multicolumn{2}{c|}{ naziv bolesti } \\
\hline $\begin{array}{l}\text { Politika (latinično onlajn } \\
\text { izdanje) }\end{array}$ & $\begin{array}{l}6.3 .2020 . \\
\text { koronavirus } \\
\text { korona virus } \\
\text { kovid 19 } \\
\text { Kovid-19 }\end{array}$ & kovid-19 & $\begin{array}{l}\text { Kovid-19 } \\
\text { kovid-19 }\end{array}$ & $/$ \\
\hline
\end{tabular}




\begin{tabular}{|l|l|l|l|}
\hline www.covid19.rs & kovid-19 & & \\
\hline & корона вирус & Коронавирус 2019 COVID- \\
COVID-19 & 19 \\
корона вирус (COVID-19) & \\
2019-nCoV & \\
коронавирус (kao jedan iz & \\
grupe) & \\
Kopoнa вируси (Cov) (kao & \\
grupa virusa) & \\
\hline
\end{tabular}

Jasno je, dakle, da u javnoj komunikaciji na srpskom jeziku postoji više naziva za virus i bolest, ali i više načina pisanja. Posebno čudi terminološka neujednačenost $i$ nepreciznost na veb-sajtu www.covid19.rs jer je reč o zvaničnom kanalu preko kog država (Ministarstvo zdravlja) i struka (Institut za javno zdravlje „Dr Milan Jovanović Batut") informišu građanstvo o aktuelnoj temi. Dok virus nije imao zvanično ime u upotrebi je bio privremeni naziv 2019-nCoV (prema Novel Coronavirus (2019-nCoV) koji je privremeno odredila Svetska zdravstvena organizacija), koji je i kod nas korišćen u zvaničnim podacima na navedenom sajtu, ali je očigledno da terminološka doslednost nije postignuta. Zanimljivo je primetiti da se prvog dana zvaničnog registrovanja virusa u zemlji pojavljuje mnogo veći broj naslova u Politici nego pola godine kasnije (iako znamo da je tema i dalje i te kako aktuelna).

Odbor za standardizaciju srpskog jezika reagovao je relativno brzo po pojavi ovih različitih naziva, te u odluci od 4.2.2020. godine iznosi mišljenje da je "najispravnije pisati: virus korona, dakle, tako što se atribut virus piše na prvom mestu. "6 Naime, u ovom saopštenju, koje potpisuje predsednik Odbora prof. dr Sreto Tanasić, kaže se da je reč o atributivnoj konstrukciji u kojoj, po pravilu, širi pojam dolazi ispred užeg, kao npr. reka Morava, drvo orah, bakterija stafilokoka. U objavi se, takođe, konstatuje da se ovaj redosled pod uticajem engleskog jezika često menja, pa se susrećemo sa oblikom korona virus u kom je prva reč nepromenljiva, ali Odbor kao najispravniji oblik ističe virus korona.

Dr Marina Nikolić na sajtu za jezičku kulturu Jezikofil (za koji, inače, postoji link na sajtu Odbora za standardizaciju srpskog jezika, te se, verujemo, smatra relevantnim) u tekstu od 7.2.2020. godine podseća da su „koronavirusi opšte ime za grupu virusa, dobijeno na osnovu izgleda, koji asocira na venac (lat. corona)"7. Pošto konkretan novi virus u tom momentu još nije imao zvanično ime, Nikolić predlaže da se do njegovog formiranja koristi naziv cele gurpe.

\footnotetext{
${ }^{6}$ Odluka je objavljena na sajtu Odbora 8.4.2020. godine: http://www.ossj.rs/odluke-i-saopstenja/pisanjenaziva-jednog-virusa/ (ovde je dostupan pdf dokument)

7 http://jezikofil.rs/koronavirusi/
} 
Imajući u vidu iznenadnu pojavu virusa, njegovo veoma brzo širenje, zatečenost celog sveta i opštu pometnju, ne čudi da je i stanje jezika po ovom pitanju turbulentno. Javna komunikacija na srpskom jeziku od početka je iz aspekta terminologije prilično nestabilna, dok, kao što vidimo, jezički stručnjaci iznose i obrazlažu konkretne stavove. Ipak, ni dva navedena stručna stava ne nude jasno i konačno rešenje za naziv virusa, što je razumljivo jer je, zapravo, virus imenovan kasnije (11.2.2020. godine).

Uzimajući u obzir veoma heterogenu jezičku praksu $s$ jedne i jasne zvanične nazive virusa i bolesti na engleskom jeziku sa druge strane, trebalo bi razmotriti koja bi to terminološka rešenja u srpskom bila veran prenos originala i time zadovoljila potrebe struke, bila jasna i funkcionalna, ali i jezički ispravna i prihvatljiva kao deo korpusa.

Pravopis srpskoga jezika (Pešikan et al., 2013: 146) u delu u kom se govori o verzalnim skraćenicama (akronimima) navodi da su one sastavljene od početnih slova višečlanog naziva i da se pišu velikim slovima bez skraćeničkih tačaka i međuslovnih belina. Navodi se da akronimi, zapravo, funkcionišu kao posebna kategorija reči koja se na specifičan i složen način uklapa u morfološki sistem. Zbog raznovrsnosti ovog tipa skraćenica, normativne neuređenosti i nestalnosti, Pravopis (Pešikan et al., 2013: 147) daje samo okvirna pravila ilustrujući ih primerima koji su duže u upotrebi.

Kada je reč o načinu pisanja stranih verzalnih skraćenica, u koje bi spadali i naziv novog virusa i bolesti, Pravopis nudi tri opcije:

preuzimanje u izvornom obliku: WHO (World Health Organization), FBI (Federal Bureau of Investigation), NBA (National Basketball Association), te bi u tom slučaju naziv virusa i bolesti na srpskom jeziku trebalo da bude SARS-CoV-2, odnosno COVID-19 (velikim slovima i u originalnoj grafiji, kako u latiničnim, tako i u ćiriličnim tekstovima);

preslovljavanje u ćirilicu (uz prilagođavanje inventaru srpske ćirilice, $\mathrm{npr} . \mathrm{W} \rightarrow \mathrm{B}, \mathrm{C} \rightarrow \mathrm{K}$ ): ВХO (World Health Organization), ФБИ (Federal Bureau of Investigation), НАTO, te bismo u tom slučaju imali virus САРС-КОВ-2 i bolest КОВИД-19;

preradu prema čitanju: BBC (British Broadcasting Corporation) $\rightarrow$ БиБи-Си (іz Би-Би-Сија) і verbalizovano Бибиси (iz Бибиси-ја), a ova varijanta, kako se nama čini, bila bi isuviše komplikovana za primenu na naziv novog virusa i bolesti. 
Dakle, može se zaključiti da bi potencijalna rešenja za pisanje naziva novog virusa na srpskom jeziku mogla biti SARS-CoV-2 koji je upotrebljiv, kako u ćiriličnim, tako i u latiničnim tekstovima i $C A P C-K O B-2$ koji bi se mogao koristiti samo u ćiriličnim tekstovima. Pošto bi sam naziv u srpskom jeziku bio uvek praćen rečju virus, morfoloških prepreka, odnosno problema pri deklinaciji ne bi bilo, jer bismo mogli reći, npr: veliki broj osoba zaražen je virusom SARS-CoV-2 / велики број особа заражен је вирусом SARS-Cov-2 / велики број особа заражен је вирусом SARS-CoV-2 / велики број особа заражен је вирусом САРС-КоВ-2.

Što se tiče pisanja naziva bolesti, iz navedenih zaključaka donesenih na osnovu smernica Pravopisa, moglo bi se reći da imamo dve varijante pisanja: COVID-19 i КОВИД-19.

Ipak, ako detaljnije konsultujemo Pravopis srpskoga jezika (Pešikan et al., 2013: 149), možemo zaključiti da bi u srpskom jeziku zvanično ustanovljeni nazivi za bolest COVID-19 mogao posmatrati i kao verbalizovana skraćenica. Naime, kako se u Pravopisu navodi, ovakve skraćenice nastaju pretvaranjem verzalnih skraćenica (akronima) u celovite reči (direktno ili spelovanjem) ili kombinovanjem formanata ili višečlanih izraza. Ovaj postupak obično se primenjuje kod skraćenica koje imaju duži vek i širu upotrebu. Za skraćenicu koja predstavlja naziv nove bolesti svakako ne možemo reći da ima dug vek jer je nova, ali ima i te kako široku upotrebu. Ako tome dodamo činjenicu da će njena pojava izvesno biti zapamćena u svetskoj istoriji, verujemo da se u jeziku može tretirati kao verbalizovana skraćenica. Ovakvi akronimi, zapravo, gube status skraćenica i, kako se u Pravopisu navodi, podležu morfološkim pravilima običnih reči.

Kao primer verbalizovanih skraćenica u Pravopisu (Pešikan et al., 2013: 149), između ostalih, nalazimo sledeće primere:

- Авној (од Авноја итд., према АВНОJ, од АВНОJ-а итд. Антифашистичко в(иј)еће народног ослобођења Југославије);

- Бемус (на Бемусу итд., поред БЕМУС, на БЕМУС-у итд. Београдске музичке свечаности);

- Фифа (из Фифе, Фифин итд.) - према FIFA

- Haca (према NASA, Насини планови);

- ЦЦија (из Ције, Цијин агент) - према CIA. 
Sledeći navedene primere verbalizovanih skraćenica, naziv nove bolesti u srpskom jeziku mogao bi se, pored prethodno navedenih varijanti akronima COVID19 (u latiničnim i ćiriličnim teksotvima) і КОВИД-19 (u ćiriličnim tekstovima), pisati i kao kovid-19 (u latiničnim tekstovima) odnosno ковид-19 (u ćiriličnim tekstovima).

Kada govorimo o deklinaciji naziva bolesti, u prvom slučaju, kod akronimima COVID-19 і КОВИД-19 pogledaćemo dva pravila koja daje Pravopis (Pešikan et al., 2013: 147-148). Za domaće promenljive i strane skraćenice koje se prirodno i u neokrnjenom obliku uklapaju u naš morfološki sistem (u standardnom neizmenjenom vidu ili sa pretpostavljenim spelovanjem), oblike padeža dobijali bismo dopisivanjem padežnih nastavaka malim slovom i sa crticom: npr. iz NATO-a, u FBI-ju, iz BBC-ja, na CD-u. Kada su, pak, skraćenice (domaće ili strane) u datoj formi akronima nepromenljive, ili kada nije stvoren običaj da se pri govorenju speluju, isključeno je pisanje morfoloških nastavaka: od EU, iz SAD, u UN. Pravopis ne daje primere za skraćenice koje poput COVID-19 / КОВИД-19 sadrže i crticu i broj, a imajući u vidu njihovu kompleksnu grafiju, verovatno bi bilo najbolje rešenje izostavljanje morfološki nastavaka, npr.: oboleli od COVID-19 / оболели од COVID-19 / оболели од КОВИД19, suočavanje sa COVID-19 / суочавање са КОВИД-19.

S druge strane, kovid-19 / ковид-19 kao verbalizovana skraćenica oblike padeža bi dobijao tako što bi se reč kovid deklinirala, a crtica i broj bi ostajali, te bismo imali, npr.: oboleli od kovida-19 / оболели од ковида-19, suočavanje sa kovidom-19/ суочавање са ковидом-19.

\subsection{Naziv virusa i bolesti u španskom jeziku}

Kraljevina Španija prvi slučaj novog virusa zvanično je registrovala 31.1.2020. godine, a dnevni list El País u svom onlajn izdanju toga dana njegov naziv spominje u četiri naslova8:

1. Sanidad confirma en La Gomera el primer caso de coronavirus en España

2. Los bulos del coronavirus, un peligroso brote de confusión y desconfianza

3. Madrid establece un protocolo para el coronavirus

\footnotetext{
${ }^{8}$ Kao i u prethodnom slučaju, uzeli smo u obzir cele tekstove, a ovde izdvajamo samo naslove; podebljanja reči u naslovu su naša.
} 
4. El coronavirus de Wuhan | España estima que la epidemia puede "remitir pronto"

Pola godine nakon što je potvrđen prvi slučaj zaraze, 30.6.2020. godine u onlajn izdanju istog dnevnog lista pronalazimo sledećih devet naslove koji sadrže naziv virusa:

1. Confirmado el primer caso de coronavirus en el mayor campamento de migrantes en la frontera de México y EE UU

2. Los alcaldes mantienen la presión al Gobierno para destinar sus ahorros a los gastos del coronavirus

3. Cataluña vigila nueve brotes de covid-19, ocho de ellos en la provincia de Lleida

4. La carta abierta del Marañón a sus pacientes tras la crisis del coronavirus: "Habéis sido nuestra familia"

5. Pedro Duque calcula que España tendrá dosis de vacuna contra la covid "a principios del año que viene"

6. El impacto del Covid-19 en el ámbito parlamentario

7. ¿Serán los niños los grandes perjudicados de los rebrotes del coronavirus?

8. Duque recibe críticas por decretar días sin IVA en plena pandemia de coronavirus en Colombia

9. Pulseras en la universidad y pupitres en el gimnasio del instituto, un repaso a las medidas de seguridad en la selectividad del coronavirus

Španska država svoje građane o situaciji sa virusom informiše putem sajta Ministarstva zdravlja ${ }^{9}$, a na njemu smo na španskom jeziku našle sledeće:

\section{Enfermedad por el coronavirus (COVID-19);}

Actualización n. 299: enfermedad por SARS-CoV-2 (COVID-19):

Govornici španskog jezika mogu da konsultuju i sajt Svetske zdravstvene organizacije na tom jeziku gde se sada već nedvosmisleno može naći podatak da je na

${ }^{9}$ https://www.mscbs.gob.es/profesionales/saludPublica/ccayes/alertasActual/nCov/situacionActual.htm?q= service/ 
španskom jeziku virus coronavirus de tipo 2 causante del síndrome respiratorio agudo severo, skraćeno SARS-CoV-2, a da je bolest COVID-1910.

Objedinjujući sve nazive za virus i bolest koje smo identifikovale u španskom jeziku, dobijamo sledeće termine:

\begin{tabular}{|l|l|l|l|l|}
\hline \multicolumn{2}{|c|}{ Izvor } & \multicolumn{1}{|c|}{ naziv virusa } & \multicolumn{2}{c|}{ naziv bolesti } \\
\hline & 31.1 .2020$. & 30.6 .2020$. & 31.1 .2020$. & 30.6 .2020$. \\
\hline El País (onlajn izdanje) & $\begin{array}{l}\text { coronavirus } \\
\text { Covid-19 } \\
\text { el coronavirus } \\
2019-n \text { CoV }\end{array}$ & coronavirus & covid-19 & $\begin{array}{l}\text { covid-19 } \\
\text { (la) covid } \\
\text { (el) } \\
\text { Covid- } \\
19\end{array}$ \\
\hline $\begin{array}{l}\text { Veb-sajt Ministarstva } \\
\text { zdravlja }\end{array}$ & $\begin{array}{l}\text { SARS-CoV-2 } \\
\text { coronavirus (kao jedan iz grupe) }\end{array}$ & COVID-19 \\
\hline
\end{tabular}

Kao što možemo primetiti, terminološka slika u španskom jeziku ujednačenija je od one u srpskom, ali i u njoj postoje izvesne nedoumice. $U$ analiziranim novinskim tekstovima zvaničnim nazivom za bolest (COVID-19) označava se i virus, a piše se malim slovima ili velikim početnim slovom. Kod naziva bolesti, osim oscilacija u pisanju malim i velikim početnim slovom, javlja se i dilema oko roda, te se susreću i muški i ženski. Važno je istaći da zvaničan sajt Ministarstva zdravlja pokazuje doslednost u upotrebi zvaničnih termina za naziv virusa i bolesti (dok oni nisu bili ustanovljeni u upotrebi je bio preporučeni privremeni naziv el coronavirus 2019-nCoV od engleskog Novel Coronavirus (2019-nCoV)), a nema dvoumljenja ni kada je način pisanja u pitanju. Za razliku od Politike, El País beleži mnogo više naslova koji sadrže naziv virusa i/ili bolesti pola godine nakon registrovanja prvog slučaja zaraze u Španiji, nego na dan kada je prvi slučaj zvanično identifikovan.

Španska kraljevska akademija u tekstu pod naslovom Crisis del COVID-19: sobre la escritura de coronavirus ${ }^{11}$, objavljenom 18.3.2020. godine, osvrće se na uticaj zdravstvene situacije na jezik, konstatujući da jezik nikako nije otporan na društvene događaje, pa ni na aktuelnu pandemiju. U prilog tome govori i činjenica da su neke od najzastupljenijih reči u rečničkim pretragama u poslednje vreme upravo reči iz aktuelnog društvenog konteksta - coronavirus (koronavirus), pandemia (pandemija), epidemia (epidemija), cuarentena (karantin), hipocondría (hipohondrija), asintomático (asimptomatski) i slične. Nove situacije stvaraju nove reči u jeziku, ali uprkos tome što su u jednom momentu vrlo česte u upotrebi, one obično budu kratkog veka.

10 https://www.who.int/es/emergencies/diseases/novel-coronavirus-2019/technical-guidance/naming-thecoronavirus-disease-(covid-2019)-and-the-virus-that-causes-it

${ }^{11}$ https://www.rae.es/noticias/crisis-del-covid-19-sobre-la-escritura-de-coronavirus 
Reč coronavirus još uvek nije našla mesto u Rečniku Španske kraljevske akademije (ali je uzeta u razmatranje i verovatno će se u njemu i naći), te Akademija u spomenutom tekstu daje smernice za njeno pisanje i kaže da je u pitanju jedna reč koja predstavlja zajedničko ime virusa (tj. naziv za grupu), odnosno imenica muškog roda koja ima isti oblik za jedninu i množinu - el coronavirus / los coronavirus. Naziv beleži se i u Rečniku medicinskih termina Nacionalne kraljevske akademije za medicinu (Diccionario de términos médicos de la Real Academia Nacional de Medicina). Pozivajući se na Svetsku zdravstvenu organizaciju, Španska kraljevska akademija navodi i puno ime virusa el SARS-CoV-2, kao i termin kojim je označena bolest COVID-19. Kada je reč o terminu kojim se označena bolest, u upotrebi se javlja u gramatičkom obliku imenice muškog roda u jednini el COVID-19, iako je u španskom jeziku bolest, la enfermedad, imenica ženskog roda. Španska kraljevska akademija objašnjava činjenicu da se bolest označava imenicom muškog roda uticajem roda imenice el coronavirus, ali i nazivima drugih virusnih bolesti, kao što su el zika, el ébola. Konačno, za naziv bolesti ovo telo odobrava upotrebu i muškog i ženskog roda (el COVID-19 i la COVID-19), napominjući da je prva češća zbog navedene analogije, a da je i druga ispravna imajući u vidu da je reč bolest ženskog roda u španskom jeziku. Budući da je reč o novijem akronimu Akademija sugeriše pisanje velikim slovima. Ako bi se vemenom reč ustalila kao naziv bolesti, trebalo bi je pisati malim slovom covid-19. S obzirom na to da ne postoji posebno pravilo za izgovaranje akronima, reč se akcentuje sledeći primere reči sa sličnom strukturom -[koßíd].

\section{Zaključna razmatranja i teme za buduća istraživanja}

Imajući u vidu analizu termina kojim su označeni novi respiratorni virus i bolest koju on uzrokuje u srpskom i španskom jeziku, možemo zaključiti da su u oba jezika postojale izvesne nedoumice kada je reč o formiranju ovih termina.

Zajedničko pitanje u oba jezika bilo je da li se koronavirus (coronavirus) piše kao jedna ili kao dve reči (corona virus). Ova nedoumica bila je jedna od najbrže otklonjenih u oba jezika, jer je shvaćeno da se radi o terminu kojim se označava cela grupa virusa, a ne novi virus, i da se naziv za grupu piše kao jedna reč - koronavirus/ coronavirus u jednini, ako govorimo o jednom virusu iz grupe, odnosno koronavirusi/ coronavirus u množini, ako je reč o više njih ili celoj grupi. Ova nedoumica bila je izraženija u srpskom jeziku, te smo imali varijante korona virus i virus korona. Dr Marina Nikolić u spomenutom tekstu odmah je skrenula pažnju da je reč o grupi virusa koju treba pisati kao jednu reč, a da novi virus u tom momentu još nije bio imenovan. 
Odboru za standardizaciju srpskog jezika izgleda da je promakla činjenica da je reč o grupi virusa, te je sugerisao da se, sledeći pravilo pisanja atributivnih konstrukcija, u srpskom jeziku koristi oblik virus korona. Reakcija Odbora bila je brza, ali čudi da posle nje nije bilo dodatnih, kada je virus zvanično imenovan u svetu, a govornici srpskog jezika ostali su bez preciznih smernica struke kako da imenuju i u usmenoj i pisanoj komunikaciji koriste nazive za virus i bolest (a o njima veoma često govore i pišu).

Kada su Međunarodni komitet za taksonomiju virusa i Svetska zdravstvena organizacija dali zvanične nazive virusa i bolesti na engleskom jeziku, u španskom je situacija postala mnogo jasnija - reč je o virusu SARS-CoV-2 koji izaziva bolest COVID19. Najčešća greška koja se mogla naći u tekstovima na španskom jeziku bila je pisanje ovih termina, koji su u suštini akronimi, malim slovom, ili pak samo početnim velikim slovom (covid-19, Covid-19). Španska kraljevska akademija sugerisala je pisanje svim velikim slovima (COVID-19) jer je u pitanju akronim, ostavljajući mogućnost da, ako ako se termin ustali kao naziv za bolest bude pisan malim slovima (covid-19). Akademija je, takođe, otklonila nedoumicu i kada je u pitanju rod, te je u španskom prihvatljivo da ova bolest bude kako muškog (el COVID-19), tako i ženskog roda (la COVID-19).

Kako u srpskom, tako i u španskom jeziku, pun naziv virusa (SARS-CoV-2) spominje se znatno ređe od naziva za grupu virusa (koronavirusi/ coronaviruses) ili bolest (COVID-19).

I nakon zvaničnog utvrđivanja naziva virusa i bolesti, poseban izazov za srpski jezik predstavljaju padeži i ćirilično pismo, te smo konsultovanjem aktuelnog Pravopisa srpskoga jezika, došli do zaključka da bi termin za virus na srpskom jeziku mogao biti SARS-CoV-2, a za bolest COVID-19 (kao verzalne skraćenice u latiničnim i u ćiriličnim tekstovima), odnosno САРС-КОВ-2 і КОВИД-19 (kao verzalne skraćenice u ćiriličnim tekstovima). Ovi oblici bili bi nepromenjivi (zaraženi virusom SARS-CoV-2 / заражени вирусом SARS-CoV-2 / заражени вирусом CAPC-KoB-2; strah od COVID-19/ страх од COVID-19 / страх од КОВИД-19; terapija COVID-19 / терапија за COVID-19; терапија за кОВИД-19). Naziv za bolest mogao bi biti posmatran kao verbalizovana skraćenica, tj. verzalna skraćenica koja je izgubila status akronima i bila podložna morfološkim pravilima običnih reči: kovid-19, odnosno ковид-19 (npr. oboleli od kovida-19 / оболели од ковида-19). Ipak, ovom postupku se pribegava ako skraćenice imaju duži vek i širu upotrebu, a u našem slučaju, reč je o novoj skraćenici, ali veoma široke upotrebe i, sudeći po posledicama koje ostavlja na savremeni svet, 
sa ozbiljnim izgledima da bude i dugog veka. Stručnjaci za srpski jezik bi svakako trebalo da daju mišljenje o najboljem rešenju.

Konačno, podsećajući da su nazivi za virus i bolest termini struke, iako su ušli u široku generalnu upotrebu, kako smo videli iz navedenih istraživanja, ipak treba da zadovolje ključne kriterijume jednoznačnosti, nesinonimnosti, kratkoće i internacionalnosti. Kako u srpskom, tako i u španskom jeziku, kriterijum internacionalnosti, odnosno međujezičke prozirnosti, jeste zadovoljen, jer je zapravo reč o internacionalnim akronimima. Moglo bi se reći i da je kriterijum kratkoće zadovoljen, iako termin kojim je označen virus (SARS-CoV-2) jeste prilično dug, ali što je bitnije, ispunjava kriterijume nomenklature virusa. Pošto je reč o novoformiranim terminima oni imaju samo jedno značenje, ali smo primetile u analiziranim slučajevima da se u španskom, a još češće u srpskom jeziku termin COVID-19, koji je naziv za bolest, koristi i kao naziv za virus, što bi, svakako trebalo izbegavati i osigurati terminima jednoznačnost. $U$ predstavljenoj analizi primetile smo i da kriterijum nesinonimnosti nije u potpunosti zadovoljen ni u španskom (gde se naziv bolesti piše svim malim, ali i svim velikim slovima), a opet posebno u srpskom jeziku (gde se u istom značenju koriste varijante covid-19 / ковид-19 pisane svim malim i velikim slovima, sa crticom i bez crtice, velikim i malim početnim slovom).

U ovom radu (što je vidljivo već u naslovu i apstraktu) opredelile smo se da kao termin za virus koristimo (nepromenjivu) verzalnu skraćenicu SARS-CoV-2, a kao termin za bolest, verbalizovanu skraćenicu kovid-19, koja se više ne ponaša kao akronim, već podleže morfološkim pravilima (pa u naslovu imamo oblik lokativa „u doba pandemije kovida-19"). Budući da u zvaničnom srpskom jeziku još ne postoje jasne terminološke, gramatičke i pravopisne smernice za imenovanje aktuelnog virusa i bolesti, ostavljamo prostor da je moguće da naš izbor nije najbolji, te ćemo ga rado ponovo razmotriti čim budemo imali zvaničan stav naših stručnjaka (očigledno potreban nama, ali i celokupnoj stručnoj i široj javnosti radi jasne, nedvosmislene i jezički ispravne opšte i stručne, pisane i usmene komunikacije).

$U$ toku istraživanja vršenih za potrebe ovog rada, prepoznale smo i brojna druga polja u vezi sa datom temom, koja otvaraju prostor novim istraživanjima. Naime, mogla bi se praviti komparativna analiza terminologije koja se koristi da označi ključne pojmove aktuelne pandemije sa terminologijom koja se upotrebljavala kada su bili prisutni virusi ptičjeg gripa, svinjskog gripa i sl. (iako se može pretpostaviti da je sama tema zaraze tada bila manje prisutna, nego što je to slučaj sa kovidom-19, zbog posledica koje ostavlja na funkcionisanje celog sveta). Takođe bi bilo interesantno 
istražiti koje termine u slučaju aktuelne pandemije koristi medicinska struka u svakodnevnoj komunikaciji i da li su oni drugačiji od termina koji se mogu naći u medijima.

Uočile smo i niz novih izraza poput kovid-ambulanta, kovid-bolnica, kovid-zona i sl., kao i kolokvijalizme poput reči koronaš koji bi se mogli analizirati detaljnije u nekim narednim radovima. Takođe smo registrovale i prisustvo nove reči - kovidiot, koja označava osobu koja ne poštuje mere sprečavanja širenja zaraze ili pak ne priznaje ozbiljnost epidemiološke situacije. Njeno postojanje beleži i Jezikofil ${ }^{12}$, primećujući da se radi o slivenici nastaloj od reči kovid i idiot, a koja će verovatno postati internacionalni neologizam. Reč je nastala u engleskom (covidiot), a postoji i u španskom (covidiota), kao i u mnogim drugim jezicima. Prostor daljim jezičkim istraživanjima otvaraju i pojmovi i termini koji se koriste u formulisanju mera sprečavanja širenja zaraze poput, u srpskom često prisutne socijalne distance (u španskom distanciamiento social), sugestija da se ostane kod kuće/ kući/ doma itd.

Kao što je i samim naslovom ovog teksta određeno, naš trenutni fokus usmeren je na terminološka rešenja koja se tiču naziva aktuelnog virusa i bolesti u španskom i srpskom jeziku, a periodu pred nama ćemo se pozabaviti i nekom od brojnih drugih jezičkih tema koje nam nameće data situacija.

\section{Literatura}

\section{Bibliografija}

Bugarski, R. (1976). Jezik i društvene promene. Polja, 203, 2-5. Novi Sad: Kulturni centar Novog Sada.

Bugarski, R. (2007). Lingvistika u primeni. Beograd: Čigoja štampa.

Cabré, M. T. (1999). Terminology: Theory, Methods and Applications. Amsterdam: John Benjamins Publishing Co.

Đordan, A. (2016). Jezička politika i terminologija u profesionalnim domenima jezičke upotrebe u standardnom španskom i srpskom jeziku (doktorska disertacija u rukopisu). Filološki fakultet, Univerzitet u Beogradu, Srbija.

Filipović, J., Filipović, J. (1997). General Trends in Standardization of Scientific Terminology in Serbian: A Critical Analysis of the State of Affairs. International conference on terminology. Donostia - San Sebastian, Spain., 285-291.

\footnotetext{
${ }^{12}$ http://jezikofil.rs/ko-je-kovidiot/?lang=lat
} 
Gao, LX., Zhang, LJ. (2020). Teacher Learning in Difficult Times: Examining Foreign Language Teachers' Cognitions About Online Teaching to Tide Over COVID-19. Frontiers in Psychology (11): 549653. https://doi.org/10.3389/fpsyg. 2020.549653

Lérat, P. (1989). Les fondements théoriques de la terminologie. La Banque des mots, special issue. 51-62.

Li, J., Xie, P., Ai, B., \& Li, L. (2020). Multilingual communication experiences of international students during the COVID-19 Pandemic. Multilingua, 39(5), 529539. doi: https://doi.org/10.1515/multi-2020-0116

Milić, M. (2013). Stvaranje, standardizacija i kodifikacija sportske terminologije u srpskom jeziku. U: Silaški N. \& T. Đurović (ur.) Aktuelne teme engleskog jezika nauke i struke u Srbiji: tematski zbornik radova. Beograd: Centar za izdavačku delatnost Ekonomskog fakulteta u Beogradu, 79-89.

Pešikan, M., Jerković J. \& M. Pižurica. (2013). Pravopis srpskoga jezika. Novi Sad: Matica srpska.

Piller, I., Zhang, J., \& Li, J. (2020). Linguistic diversity in a time of crisis: Language challenges of the COVID-19 pandemic. Multilingua, 39(5), 503-515. doi: https://doi.org/10.1515/multi-2020-0136

Šipka, D. (1998). Osnovi leksikologije i srodnih disciplina. Novi Sad: Matica srpska.

Zhang, J., \& Wu, Y. (2020). Providing multilingual logistics communication in COVID19 disaster relief. Multilingua, 39(5), 517-528. doi: https://doi.org/10.1515/multi-2020-0110

Zheng, Y. (2020). Mobilizing foreign language students for multilingual crisis translation in Shanghai. Multilingua, 39(5), 587-595. doi: https://doi.org/10.1515/multi-2020-0095

\section{Sajtografija}

https://www.who.int/emergencies/diseases/novel-coronavirus-2019/technicalguidance/naming-the-coronavirus-disease-(covid-2019)-and-the-virus-thatcauses-it (veb-sajtu pristupljeno 20.9.2020)

https://covid19.rs/ (veb-sajtu pristupljeno 20.9.2020)

https://www.mscbs.gob.es/profesionales/saludPublica/ccayes/alertasActual/nCov/sit uacionActual.htm (veb-sajtu pristupljeno 20.9.2020)

http://www.ossj.rs/odluke-i-saopstenja/pisanje-naziva-jednog-virusa/ (veb-sajtu pristupljeno 17.9 .2020$)$ 
http://jezikofil.rs/koronavirusi/ (veb-sajtu pristupljeno 17.9.2020)

https://www.mscbs.gob.es/profesionales/saludPublica/ccayes/alertasActual/nCov/sit

uacionActual.htm?q=service/ (veb-sajtu pristupljeno 20.9.2020)

https://www.who.int/es/emergencies/diseases/novel-coronavirus-2019/technical-

guidance/naming-the-coronavirus-disease-(covid-2019)-and-the-virus-that-

causes-it (veb-sajtu pristupljeno 20.9.2020)

https://www.rae.es/noticias/crisis-del-covid-19-sobre-la-escritura-de-coronavirus

(veb-sajtu pristupljeno 17.9.2020)

http://www.politika.rs/articles/archive/2020/03/06 (veb-sajtu pristupljeno

15.9.2020)

http://www.politika.rs/articles/archive/2020/09/06 (veb-sajtu pristupljeno

15.9.2020)

https://elpais.com/hemeroteca/2020-01-31/ (veb-sajtu pristupljeno 16.9.2020)

https://elpais.com/hemeroteca/2020-06-30/ (veb-sajtu pristupljeno 16.9.2020)

\section{Summary \\ LANGUAGE IN THE TIME OF COVID-19: TERMINOLOGICAL SOLUTIONS IN SERBIAN AND SPANISH}

The outbreak of a pandemic caused by the Sars-CoV-2 virus resulted in numerous crashes in all spheres of modern human life. Naturally, the virus and the disease it causes have been brought to the centre of attention of the entire world in recent months. Information about them and all the measures taken to prevent the spread of the virus are being published in all living languages and transmitted through all communication channels (print and electronic media, social networks, websites of official health and government institutions, oral and written statements, etc.). The aim of this paper is to analyse a corpus consisting of media texts and official statements of relevant institutions (primarily of the Wold Health Organisation and competent bodies in Serbia and Spain) in order to observe terminological solutions used to name the virus and the disease in both Serbian and Spanish. It will draw attention to certain terminological, orthographic and grammatical dilemmas that have arisen in the process. The starting hypothesis is that, in both Serbian and Spanish, there have been dilemmas on how to name the virus and the disease and how to spell their names. Finally, the paper will offer adequate solutions for all identified linguistic inaccuracies or inconsistencies. language.

Key words: SARS-CoV-2, COVID-19, terminology, Serbian language, Spanish 